\title{
Knockdown of CCL28 inhibits endometriosis stromal cell proliferation and invasion via ERK signaling pathway inactivation
}

\author{
YINGTING WU ${ }^{1}$, FEILONG ZHU ${ }^{1}$, WENQIN SUN $^{1}$, WEIWEI SHEN $^{1}$, QIN ZHANG $^{2}$ and HUIFEN CHEN ${ }^{1}$ \\ ${ }^{1}$ Department of Laboratory Medicine, Shanghai First Maternity and Infant Hospital, School of Medicine, \\ Tongji University, Shanghai 200092; ${ }^{2}$ Phase I Clinical Trial Unit, Tongren Hospital, \\ Shanghai Jiao Tong University School of Medicine, Shanghai 200336, P.R. China
}

Received March 19, 2021; Accepted September 15, 2021

DOI: $10.3892 / \mathrm{mmr} .2021 .12573$

\begin{abstract}
Endometriosis (EM), the presence of functional endometrial glands and stroma outside the uterine cavity, is a common gynecological disorder. At present, the pathogenesis of EM has not been fully elucidated, so there is still a lack of effective therapy. The present study aimed to explore the role of C-C motif chemokine ligand 28 (CCL28) and its underlying mechanism in endometrial stromal cells to propose a novel therapy for EM treatment. The expression of CCL28 and $\mathrm{CC}$ chemokine receptor 10 (CCR10) were examined. After CCL28 knockdown or overexpression by lentivirus infection, cell proliferation and invasion were measured. It was revealed that compared with normal, the expression levels of CCL28 and CCR10 were significantly elevated in endometrial tissues of patients with EM. Knockdown of CCL28 in endometrial stromal cells significantly suppressed cell proliferation and invasion, and this was accompanied by significantly reduced expression levels of CCR10, MMP2, MMP9, integrin $\beta 1$ (ITGB1) and phosphorylated (p)-ERK/ERK ratio. The addition of the CCL28 recombinant protein had an opposite effect to CCL28 downregulation. Furthermore, the ERK inhibitor, PD98059, reduced CCL28-induced cell proliferation and invasion, as well as the expression levels of MMP2, MMP9, ITGB1 and p-ERK. Therefore, the present study indicated that CCL28 may contribute to the progression of EM by regulating MMP2, MMP9 and ITGB1 expression and function via the activation of the ERK signaling pathway.
\end{abstract}

Correspondence to: Dr Huifen Chen, Department of Laboratory Medicine, Shanghai First Maternity and Infant Hospital, School of Medicine, Tongji University, 536 Changle Road, Jingan, Shanghai 200092, P.R. China

E-mail: chf51mch@126.com

Dr Qin Zhang, Phase I Clinical Trial Unit, Tongren Hospital, Shanghai Jiao Tong University School of Medicine, 1111 Xianxia Road, Changning, Shanghai 200336, P.R. China

E-mail: zq1980@shtrhospital.com

Key words: endometriosis, C-C motif chemokine ligand 28, endometriosis stromal cells, MMPs, integrin beta 1, ERK pathway

\section{Introduction}

Endometriosis (EM), the presence of functional endometrial glands and stroma outside the uterine cavity, is a common gynecological disorder characterized by dysmenorrhea, chronic pelvic pain, menstrual abnormalities and infertility (1-4). Previous study demonstrated that EM affects $\sim 10 \%$ of individuals who have a uterus, and that the probability of symptomatic perimenopause increases to $30-50 \%$ (5). Currently, the most common primary diagnostic method for EM is laparoscopy, supplemented with the screening for cancer antigen 125 (CA125) and endometrium antibody, as well as B-ultrasounds, x-ray and magnetic resonance imaging (6). Although EM is a benign disease, it has certain characteristics of malignant tumors, including cell invasion, new blood vessel generation, unlimited growth, reduced numbers of apoptotic cells, infiltration and destruction of surrounding tissues and metastasis (7). Therefore, inhibition of the growth and invasion of EM may be a possible treatment strategy for EM.

Chemokines are selective mediators of leukocyte migration to inflammatory sites (8). It has been demonstrated that chemokines are key players in a variety of physiological and pathological events, including chemotaxis, cell proliferation, apoptosis, angiogenesis and inflammatory processes/diseases (9,10).C-C motif chemokine ligand (CCL) 28 is a mucosa-associated epithelial chemokine that is selectively expressed in certain mucosal tissue, such as epithelial mucosal tissues $(11,12)$. CCL28 is a functional ligand for CC chemokine receptor (CCR)10, a member of the chemokine receptor family, which belongs to the $\mathrm{G}$ protein-coupled receptor superfamily, and is normally expressed by melanocytes, plasma cells and skin-homing T cells (13). Upregulation of CCR10 can facilitate cell proliferation and invasion in glioma, contributing to gliomagenesis (14). Furthermore, CCR10 can stimulate breast cancer cell invasion and migration by increasing MMP7 expression via ERK1/2 activation $(15,16)$. In ectopic endometrial stromal cells, depletion of CCL27 can suppress cell proliferation, metastasis and adhesion (17). CCL28 induces apoptosis of decidual stromal cells via binding of CCR3/CCR10 in human spontaneous abortion (18). Furthermore, estrogen may serve a crucial role in the protection against genital infection by regulating mucosa-associated epithelial chemokine (MEC)/CCL28 expression in the uterus (19). There are also several studies 
demonstrating that the ERK1/2 signaling pathway is associated with migration and apoptosis of endometrial stromal cells (20-24). Another study has reported that CCL28 can promote cell proliferation and metastasis in breast cancer via the MAPK signaling pathway (25). However, the function of CCL28 in endometrial stromal cells and its underlying mechanisms are still unknown.

The present study aimed to explore the role of CCL28 and its underlying mechanism in endometrial stromal cells to propose a novel therapy for EM treatment. It provided important leads for designing studies in the future to understand the mechanism of EM and aid in the development of novel therapeutic strategies.

\section{Materials and methods}

Patient samples. Patients who met the EM diagnostic criteria (visual inspection/laparoscopy/laparotomy) participated in the study. EM is usually diagnosed by visual inspection of the pelvis during laparoscopy or laparotomy (6). After informed consent was obtained, the EM tissues from 15 patients (female, age range from 25 years to 55 years, mean age: 37 years, Shanghai, China) with deep-infiltrating EM who underwent laparoscopic treatment at the Shanghai First Maternity and Infant Hospital, Tongji University School of Medicine (Shanghai, China) between February 2020 and December 2020 were removed via biopsy. Deep-infiltrating EM is located $5 \mathrm{~mm}$ below the surface of the peritoneum. Control endometrial samples were collected from 15 patients (female, age range from 23 years to 51 years, mean age: 35 years, Shanghai, China) without EM who underwent laparoscopy and hysteroscopy surgery for benign gynecological diseases. CCL28 and CCR10 expression was detected in these tissues by IHC. Furthermore, 80 serum samples (healthy individuals: 40; EM patients, 40) were collected to detect CCL28 levels by ELISA. Tissue samples were collected independent of menstrual cycle stage. The following inclusion criteria were used: i) EM was confirmed by two pathologists following laparoscopic biopsy; and ii) No preoperative chemotherapy or radiotherapy was received. Patients who had received hormonal treatment and birth control prior to enrollment were excluded from the study. The clinical characteristics of the patients and controls are shown in Table I. The Ethics Committee of Shanghai First Maternity and Infant Hospital, Tongji University School of Medicine (Shanghai, China) approved all experiments involving patients.

Cell culture. Primary endometrial stromal cells derived from ectopic endometria of female patients with EM, or from normal endometria of female patients without EM, were isolated and cultured as previously described $(26,27)$. Immunocytochemistry using anti-cytokeratin 19 and anti-Vimentin antibodies was performed to identify cell purity. The cells were cultured in DMEM/F12 (cat.no. SH30023.01B; Hyclone; Cytiva) containing 10\% FBS (cat. no. 16000-044; Gibco; Thermo Fisher Scientific, Inc.), $1 \%$ double antibiotics (penicillin and streptomycin mixture), $2 \mathrm{mM}$ L-glutamine and $1 \mathrm{ng} / \mathrm{ml}$ fibroblast growth factor- 2 at $37^{\circ} \mathrm{C}$ in a $5 \% \mathrm{CO}_{2}$ incubator. 293T cells were cultured with DMEM containing 10\% FBS (cat. no. 16000-044; Gibco; Thermo Fisher Scientific, Inc.), $1 \%$ double antibiotics in a $37^{\circ} \mathrm{C}, 5 \% \mathrm{CO}_{2}$ incubator.
Plasmid construction and lentivirus packaging. Targeting different sites of CCL28, three interference sequences were synthesized (Table II). Short hairpin RNA (sh) constructs were created using double chain annealing and inserted into the pLKO.1-Puro vector (Addgene, Inc.) at AgeI-EcoRI restriction sites, while a negative control shRNA (shNC) as a negative control. Subsequently, plasmids of pLKO.1-Puro-shCCL28-1, -2 and -3 (1,000 ng) were co-transfected with viral packaging plasmids psPAX2 (900 ng) and pMD2.G (100 ng; Addgene, Inc.; packaging vector:envelope vector, 1:9) into 3rd generation 293T cells (ATCC) using Lipofectamine ${ }^{\circledR} 2000$ (Invitrogen; Thermo Fisher Scientific, Inc.) for $48 \mathrm{~h}$ at $37^{\circ} \mathrm{C}$ in a $5 \% \mathrm{CO}_{2}$ incubator. Following $48 \mathrm{~h}$ of incubation, viral particles were collected via ultracentrifugation at $55,000 \times \mathrm{g}, 4^{\circ} \mathrm{C}$ for $2.5 \mathrm{~h}$, and then the viral supernatant (MOI, 10) was used to infect EM stromal cells $\left(1 \times 10^{6}\right)$. After $24 \mathrm{~h}$ infection, the cells were cultured for $24 \mathrm{~h}$ with serum-free transfer solution before further experiments were performed.

ELISA. An ELISA was employed to detect CCL28 levels in the serum of patients with EM or in the supernatant of endometrial stromal cells $\left(1 \times 10^{6}\right.$ cells $\left./ \mathrm{ml}\right)$. The Human MEC/CCL28 ELISA Kit (cat. no. RAB0072; Sigma-Aldrich; Merck KGaA) was used according to the manufacturer's protocol.

Immunohistochemical (IHC) detection. Tissue sections (4 $\mu \mathrm{m})$ were washed with $0.02 \mathrm{M}$ PBS and fixed with $4 \%$ formaldehyde for $30 \mathrm{~min}$ at room temperature. After three washes with $0.02 \mathrm{M}$ PBS, samples were incubated in $0.3 \% \mathrm{H}_{2} \mathrm{O}_{2}$ in a wet-box for $10 \mathrm{~min}$ and then blocked in 1\% BSA (cat. no. A8010; Beijing Solarbio Science \& Technology Co., Ltd.) for $1 \mathrm{~h}$ at room temperature. Subsequently, samples were incubated with primary antibodies against CCL28 (1:200; cat. no. 18214-1-AP; ProteinTech Group, Inc.) and CCR10 (1:100; cat. no. 22071-1-AP; ProteinTech Group, Inc.) for 1 $\mathrm{h}$ at room temperature. The primary incubation was then followed by a 30-min incubation with HRP-labeled secondary antibodies (cat. no. D-3004; Shanghai Changdao Biological Technology Co., Ltd.) at room temperature. Samples were then subjected to 3, 3'-diaminobenzidine (DAB) staining (cat. no. FL-6001; Shanghai Changdao Biological Technology Co., Ltd.), $3 \mathrm{~min}$ of hematoxylin staining (cat. no. 714094; Zhuhai Besso Biotechnology Co., Ltd.) and alcohol differentiation with $1 \%$ hydrochloric acid at room temperature, followed by washing with tap water for $10 \mathrm{~min}$ and drying in a $65^{\circ} \mathrm{C}$ oven for $15 \mathrm{~min}$. Finally, samples were made transparent in xylene for $3 \mathrm{~min}$ and sealed with neutral gum (cat. no. G8590; Solarbio) at room temperature. After drying in a $65^{\circ} \mathrm{C}$ oven for $15 \mathrm{~min}$, samples were imaged using an upright fluorescence microscope (ECLIPSE Ni; Nikon Corporation). CCL28 and CCR10 expression was analyzed using an image analysis system version 11.0 (IMS; Beijing Changheng Rongchuang Technology).

Immunocytochemical detection. Endometrial cells were cultured on coverslips for $24 \mathrm{~h}$. The cells were washed with $0.02 \mathrm{M}$ PBS to remove the medium, fixed with $4 \%$ formaldehyde for $30 \mathrm{~min}$ at room temperature and washed with $0.02 \mathrm{M}$ PBS. Cells were permeated with $0.5 \%$ Triton X-100 (cat. no. T8200; Beijing Solarbio Science \& Technology Co., Ltd.) for $10 \mathrm{~min}$ 
Table I. Clinical characteristics of patients.

\begin{tabular}{|c|c|c|c|}
\hline Characteristics & $\begin{array}{c}\text { Patients with } \\
\text { endometriosis }(n=40)\end{array}$ & $\begin{array}{l}\text { Healthy patients } \\
\qquad(\mathrm{n}=40)\end{array}$ & P-value \\
\hline Age, year & $35.55 \pm 3.64$ & $31.32 \pm 5.87$ & 0.092 \\
\hline $\mathrm{BMI}, \mathrm{kg} / \mathrm{m}^{2}$ & $19.10 \pm 2.53$ & $21.32 \pm 2.12$ & 0.061 \\
\hline CA125, IU/ml & $23.74 \pm 2.56$ & $14.57 \pm 2.04$ & 0.013 \\
\hline \multicolumn{4}{|l|}{ EM stage, n (\%) } \\
\hline III & $21(52.5)$ & NA & \\
\hline IV & $19(47.5)$ & NA & \\
\hline \multicolumn{4}{|l|}{ Benign conditions, $\mathrm{n}(\%)$} \\
\hline Uterine myoma & NA & $8(20.0)$ & \\
\hline Endometrial hyperplasia & NA & $13(32.5)$ & \\
\hline Others & NA & $19(47.5)$ & \\
\hline Menstrual phase, n (\%) & & & 0.171 \\
\hline Proliferative & $21(52.5)$ & $27(67.5)$ & \\
\hline Secretory & $19(47.5)$ & $13(32.5)$ & \\
\hline
\end{tabular}

Data are presented as the mean \pm SD or $\mathrm{n}(\%)$. CA125, cancer antigen 125; NA, not applicable.

Table II. CCL28 sequences for gene silencing.

\begin{tabular}{ll}
\hline Target site name & \multicolumn{1}{c}{ Sequence (5'-3') } \\
\hline CCL28-1 (site: $167-185)$ & GCACGGAGGTTTCACATCA \\
CCL28-2 (site: $260-278)$ & CTGTCATCCTTCATGTCAA \\
CCL28-3 (site: $321-339)$ & GCAGTGGATGAAAGTGCAA
\end{tabular}

CCL28, C-C motif chemokine ligand 28.

at room temperature and then blocked with $1 \%$ BSA for $1 \mathrm{~h}$ at room temperature. Subsequently, cells were incubated with primary antibodies against CK19 (1:200; cat. no. ab52625; Abcam) and vimentin (1:500; cat. no. ab92547; Abcam) at $4^{\circ} \mathrm{C}$ overnight. Following primary incubation, cells were incubated for $30 \mathrm{~min}$ with HRP-labeled secondary antibodies (cat. no. D-3004; Shanghai Changdao Biological Technology Co., Ltd.). Cells were then subjected to DAB staining. Finally, cells were imaged using an upright fluorescence microscope and the expression levels of CK19 and vimentin were analyzed using an image analysis system version 11.0 (IMS; Beijing Changheng Rongchuang Technology).

Flow cytometry analysis. The EM markers of CD10 and CD90 have been detected to verify the purity of endometrial stromal cells. Endometrial stromal cells in the logarithmic growth phase were digested, resuspended and counted. Resuspended cells $(5,000,000-10,000,000)$ were centrifuged at $1,000 \mathrm{x} \mathrm{g}$ for $5 \mathrm{~min}$ to obtain the cell precipitants, and then incubated with the following antibodies: FITC Mouse Anti-Human CD10 (1:50; cat. no. 340925; BD Biosciences); FITC Mouse Anti-Human CD90 (1:100; cat. no. 561969; BD Biosciences); and FITC Mouse IgG1 (1:100; cat. no. 555748; BD Biosciences). After $30 \mathrm{~min}$ of incubation at $4^{\circ} \mathrm{C}$ in the dark, the cells were detected using a Flow cytometer (CytoFLEX; Beckman Coulter, Inc.) and analyzed using BD Accuri ${ }^{\mathrm{TM}}$ C6 Software (Version 1.0.264.21; BD Biosciences).

Cell proliferation assay. Endometrial stromal cells in the logarithmic growth phase were digested with trypsin and cultured overnight in 96-well plates (cat. no. TR4001; TrueLine) at a density of 3,000 cells/well in a $37^{\circ} \mathrm{C}, 5 \% \mathrm{CO}_{2}$ incubator. At $0,12,24$ and $48 \mathrm{~h}$ of treatment of shNC, shCCL28-1and shCCL28-2, or different concentrations of CCL28 recombinant protein $(0,5,10,20$ and $40 \mathrm{ng} / \mathrm{ml})$, or vehicle + DMSO, CCL28 + DMSO, vehicle + PD98059 and CCL28 + PD98059, Cell Counting Kit-8 (CCK-8; cat. no. CP002; SAB Biotherapeutics, Inc.) reagent and serum-free medium were mixed at a volume ratio of 1:10. Subsequently, $100 \mu \mathrm{lCCK}-8$ mixture was added to the aforementioned groups. After $1 \mathrm{~h}$ incubation at $37^{\circ} \mathrm{C}$, the optical density at $450 \mathrm{~nm}$ was measured using a microplate reader.

Cell invasion assay. Endometrial stromal cells in the logarithmic growth phase were digested with trypsin and seeded into 6-well plates at a density of 300,000 cells/well. After $24 \mathrm{~h}$ of culture at $37^{\circ} \mathrm{C}$, the stromal cells were transduced with shCCL28 (shCCL28-1, shCCL28-2) lentivirus for $48 \mathrm{~h}$, or pre-treated with PD98059 (an ERK inhibitor; $10 \mu \mathrm{mol} / \mathrm{l}$; S1177; Selleck) for $30 \mathrm{~min}$ at $37^{\circ} \mathrm{C}$. Subsequently, cells were treated with CCL28 recombinant protein for $48 \mathrm{~h}$ at $37^{\circ} \mathrm{C}$ and then collected for Transwell detection. For the cell invasion assay, a 24-well Transwell plate was used (pore size, $8 \mu \mathrm{m}$; MilliporeSigma; Merck KGaA). The upper chamber of the Transwell plate was coated with $30 \mu 1$ Matrigel at $37^{\circ} \mathrm{C}$ for $30 \mathrm{~min}$ and $2 \times 10^{5}$ cells in $200 \mu \mathrm{l}$ DMEM/F12 were added. DMEM/F12 containing 10\% FBS was added to the lower chamber. After a 48 -h incubation at $37^{\circ} \mathrm{C}$, the membrane was fixed with $4 \%$ formaldehyde and stained with $0.5 \%$ crystal violet $(1 \mathrm{ml})$ for $30 \mathrm{~min}$ at room temperature. The number 
Table III. Sequences of primers for reverse transcriptionquantitative PCR.

\begin{tabular}{ll}
\hline Gene & \multicolumn{1}{c}{ Sequence (5'-3') } \\
\hline CCL28 & F: CTGATGGGGATTGTGACTTG \\
& R: TGGTGTTTCTTCCTGTGGC \\
CCR10 & F: AGGGCTGGAGTCTGGGAAGTG \\
& R: CACGATGACGGAGACCAAGTGT \\
MMP2 & F: GGGAGTACTGCAAGTTCCCCTTCTT \\
& R: TGGAAGCGGAATGGAAAC \\
MMP9 & F: AGGACGGCAATGCTGATG \\
& R: TCGTAGTTGGCGGTGGTG \\
ITGB1 & F: AATGTAACCAACCGTAGC \\
& R: GGTCAATGGGATAGTCTTC \\
GAPDH & F: AATCCCATCACCATCTTC \\
& R: AGGCTGTTGTCATACTTC \\
\hline
\end{tabular}

CCL28, C-C motif chemokine ligand 28; CCR10, C chemokine receptor 10; ITGB1, integrin $\beta 1$; F, forward; $R$, reverse.

of invasive cells was counted at a magnification of x200 via a light microscope (XDS-500C; Shanghai Caikang Optical Instrument Co., Ltd.).

Reverse transcription-quantitative PCR (RT-qPCR). Total RNA was extracted from endometrial tissues or stromal cells using TRIzol ${ }^{\circledR}$ reagent (cat. no. 1596-026; Invitrogen; Thermo Fisher Scientific, Inc.). Total RNA was quantified and underwent RNA integrity confirmation. Total RNA $(1 \mu \mathrm{g})$ was reverse transcribed into complementary DNA using a Reverse Transcription Kit (cat. no. K1622; Fermentas; Thermo Fisher Scientific, Inc.) according to the manufacturer's instructions as follows: $37^{\circ} \mathrm{C}$ for $60 \mathrm{~min} ; 85^{\circ} \mathrm{C}$ for $5 \mathrm{~min} ; 4^{\circ} \mathrm{C}$ for $5 \mathrm{~min}$. qPCR was subsequently performed using an ABI-7300 (Applied Biosystems; Thermo Fisher Scientific, Inc.) and a SYBR-Green PCR Kit (cat. no. K0223; Thermo Fisher Scientific, Inc.). The following thermocycling conditions were used for qPCR: Initial denaturation: $10 \mathrm{~min}$ at $95^{\circ} \mathrm{C}$; followed by 40 cycles of denaturation, elongation and annealing at $15 \mathrm{sec}$ at $95^{\circ} \mathrm{C}$ and $45 \mathrm{sec}$ at $60^{\circ} \mathrm{C}$. CCL28, CCR10, MMP2, MMP9 and ITGB1 mRNA expression levels were quantified using the $2^{-\Delta \Delta C q}$ method (28) and normalized to the internal reference gene GAPDH. The primers are listed in Table III.

Western blotting. Total protein was extracted from endometrial stromal cells using RIPA buffer (containing protease and phosphatase inhibitors; cat. no. R0010; Beijing Solarbio Science \& Technology Co., Ltd.). Following total protein quantification using a BCA kit (cat. no. 23223; Thermo Fisher Scientific, Inc.), $25 \mu 1$ of protein/lane was separated via SDS-PAGE using 10 and $12 \%$ gels before being transferred onto polyvinylidene fluoride membranes (cat. no. HATF00010; MilliporeSigma; Merck KGaA). Membranes were blocked in 5\% skimmed milk (BD Biosciences) for $1 \mathrm{~h}$ at room temperature. Subsequently, membranes were incubated overnight at $4^{\circ} \mathrm{C}$, with gentle shaking, with primary antibodies against CCL28 (dilution, 1:500; cat. no. ab196567; Abcam), CCR10 (dilution, 1:250; cat. no. ab3904; Abcam), MMP2 (dilution, 1:5,000; cat. no. ab37150; Abcam), MMP9 (dilution, 1:1,000; cat. no. ab194316; Abcam), ITGB1 (1:1,000; cat. no. ab24693; Abcam), phosphorylated (p)-ERK (dilution, 1:1,000; cat. no. ab214362; Abcam), ERK (dilution, 1:10,000; cat. no. ab184699; Abcam) and GAPDH (dilution, 1:2,000; cat. no. 5174; Cell Signaling Technology, Inc.). The membranes were washed three times with TBS-0.05\% Tween-20 (TBST), followed by a 2-h incubation at room temperature with HRP-conjugated goat anti-rabbit (cat. no. A0208) and goat anti-mouse (catalog no. A0216) secondary antibody (dilution, 1:1,000; Beyotime Institute of Biotechnology). Membranes were washed with TBST and visualized using a chemiluminescent reagent (cat. no. WBKLS0100; MilliporeSigma; Merck KGaA) and ECL imaging system (Tanon-5200; Tanon Science and Technology Co., Ltd.). ImageJ version 1.47 (National Institutes of Health) was used to semi-quantify protein expression levels using GAPDH as a loading control.

Gelatinase zymography. Total protein from cells was isolated using RIPA buffer, quantified by a BCA kit (cat. no. 23223; Thermo Fisher Scientific, Inc.) and $25 \mu 1$ protein per lane was separated via $10 \%$ SDS-PAGE containing $1 \%$ gelatin. The gels were then washed with eluent $(2.5 \%$ Triton X-100, $50 \mathrm{mM}$ Tris- $\mathrm{HCl}, 5 \mathrm{mM} \mathrm{CaCl}_{2} ; \mathrm{pH}$ 7.6) twice for $30 \mathrm{~min}$, and rinsed with rinsing solution (eluent without Triton X-100) twice for $20 \mathrm{~min}$. The gels were subsequently incubated in incubation solution $\left(50 \mathrm{mM}\right.$ Tris-HCL, $5 \mathrm{mM} \mathrm{CaCl}_{2}, 0.02 \%$ brij-35; $\mathrm{pH}$ 7.6) for $20 \mathrm{~h}$ at $37^{\circ} \mathrm{C}$. The gels were stained using Coomassie brilliant blue staining solution for $3 \mathrm{~h}$ at room temperature in a low-speed shaker, and the staining solution was recovered. A decolorizing solution (30\% methanol and $10 \%$ acetic acid) was added to highlight clear bands on a blue background for $30 \mathrm{~min}$ at room temperature. Images of the gels were then captured for observation using a gel imager.

Statistical analysis. Statistical analysis was performed using GraphPad Prism version 7.0 software (GraphPad Software, Inc.). One-way ANOVA followed by Tukey's post hoc test was used for statistical comparisons among more than two groups, whereas unpaired Student's t-tests were used for statistical comparisons between two groups. For Table I, the t-test was used for age, BMI and cancer antigen-125 comparisons between the patient and control groups. The $\chi^{2}$ test was used for comparisons between menstrual phases of the patient and control groups. Data are presented as the mean \pm standard deviation of $\geq 3$ independent experimental repeats. $\mathrm{P}<0.05$ was considered to indicate a statistically significant difference.

\section{Results}

CCL28 and CCR10 are highly expressed in the serum and endometrial tissues of patients with EM. CCL28 levels in the serum of patients with EM were significantly higher compared with those of the healthy controls (Fig. 1A). Furthermore, significantly higher mRNA (Fig. 1B and C) and protein (Fig. 1D) expression levels of CCL28 and CCR10 were observed in EM tissues compared with healthy tissues. IHC staining also demonstrated the high expression levels of CCL28 and CCR10 
A

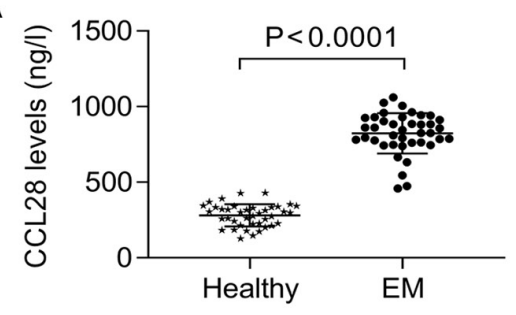

D
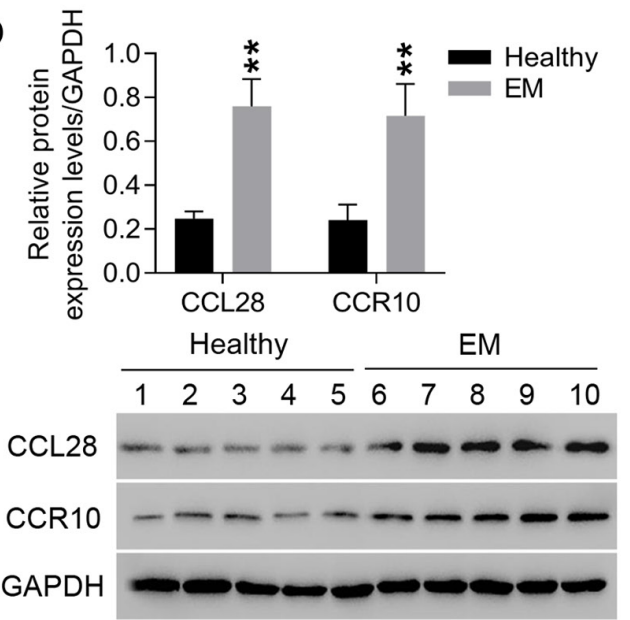

B

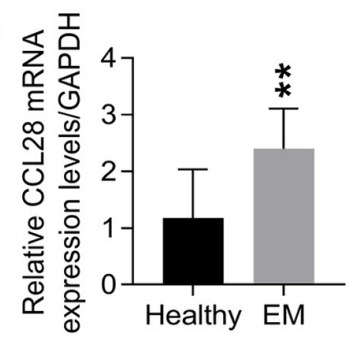

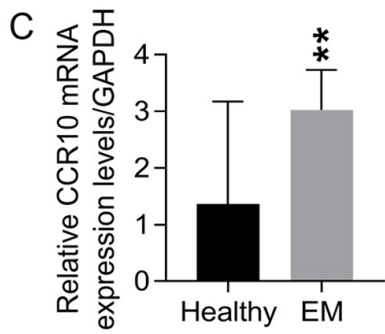

E
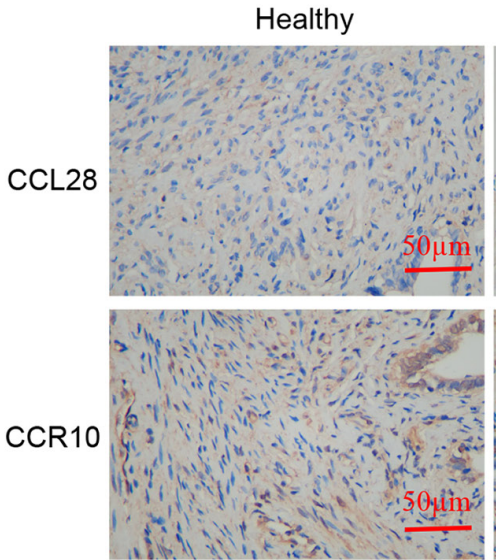
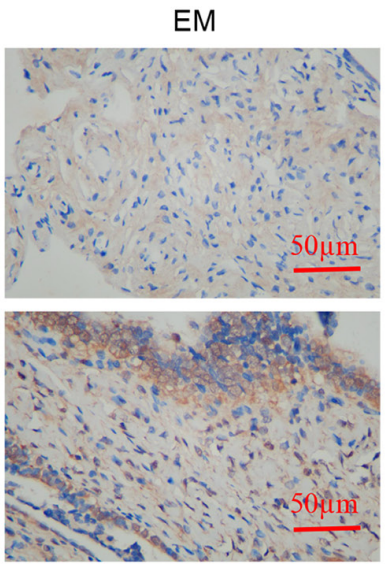

Figure 1. CCL28 and CCR10 are highly expressed in the serum and endometrial tissues of patients with EM. Serum samples of 40 patients with EM and 40 healthy patients were collected to detect CCL28 levels, and 15 endometrial tissue samples from patients with EM and 15 endometrial tissues from healthy patients were also collected. (A) CCL28 levels in the serum of patients with EM were detected using ELISA. mRNA expression levels of (B) CCL28 and (C) CCR10 in endometrial tissues of patients with EM were detected by reverse transcription-quantitative PCR. (D) Protein expression levels of CCL28 and CCR10 in endometrial tissues of patients with EM were detected using western blotting. (E) Protein expression levels of CCL28 and CCR10 in endometrial tissues of patients with EM were detected by immunohistochemistry (x200, $50 \mu \mathrm{m}$ ). ${ }^{* *} \mathrm{P}<0.01 \mathrm{vs}$. normal. CCL28, C-C motif chemokine ligand 28 ; CCR10, CC chemokine receptor 10; EM, endometriosis.

in EM tissues compared with healthy tissues (Fig. 1E). These results indicated that increased expression levels of CCL28 and CCR10 may contribute to the progression of EM.

Knockdown of CCL28 expression in endometrial stromal cells via lentiviral transduction. Positive vimentin expression was observed in ectopic endometrial stromal cells, whereas CK19 expression was negative (Fig. 2A). Vimentin is a marker of endometrial stromal cells and CK19 is a marker of epithelial cells $(29,30)$. CD10 and CD90 detection using flow cytometry verified that $>95 \%$ of the isolated cells were EM stromal cells (Fig. 2B). To understand the function of CCL28 in EM, lentiviral transduction was used to downregulate CCL28 expression in ectopic endometrial stromal cells. Both mRNA and protein expression levels of CCL28 were significantly downregulated by shCCL28-1, -2 and -3 compared with negative control (shNC; Fig. $2 \mathrm{C}$ and D). Among the three, shCCL28-1 and shCCL28-2 were more efficient and selected for use in subsequent experiments.

Knockdown of CCL28 in endometrial stromal cells significantly suppresses cell proliferation and invasion. Following CCL28 knockdown, cell proliferation and invasion were evaluated. Cell proliferation (0-48 h) and cell invasion in shCCL28 endometrial stromal cells were significantly decreased compared with those in the shNC group (Fig. 3A and B). Compared with the shNC group, a significant decrease in
CCL28 levels in the supernatant of shCCL28 endometrial stromal cells was observed (Fig. 3C). Both mRNA (Fig. 3D) and protein (Fig. 3F) expression levels of CCL28, CCR10, MMP2, MMP9 and ITGB1 in shCCL28 endometrial stromal cells were significantly reduced compared with those of shNC endometrial stromal cells. Knockdown of CCL28 also decreased the activities of MMP2 and MMP9 compared with the shNC group (Fig. 3E). Furthermore, CCL28 knockdown significantly decreased the protein expression levels of p-ERK/ERK ratio, compared with shNC (Fig. 3G). These results suggested that knockdown of CCL28 attenuated EM progression by inhibiting cell proliferation and invasion via the regulation of CCR10, MMP2, MMP9 and ITGB1 expression, and this may involve the ERK signaling pathway.

CCL28 recombinant proteins significantly increase CCL28 and CCR10 expression in healthy endometrial stromal cells. The results demonstrated that positive vimentin expression was observed in endometrial stromal cells from healthy controls, whereas CK19 expression was negative (Fig. 4A). Detection of CD10 and CD90 by flow cytometry verified that $>95 \%$ of the isolated cells were healthy endometrial stromal cells (Fig. 4B). A series of CCL28 recombinant protein concentrations $(0,5$, 10,20 and $40 \mathrm{ng} / \mathrm{ml}$ ) were used to treat healthy endometrial stromal cells. At 48 h, CCL28 could significantly promote healthy endometrial stromal cell proliferation in a dose-dependent manner compared with $0 \mathrm{ng} / \mathrm{ml}$, whereas at 0,12 and $24 \mathrm{~h}$ 
A
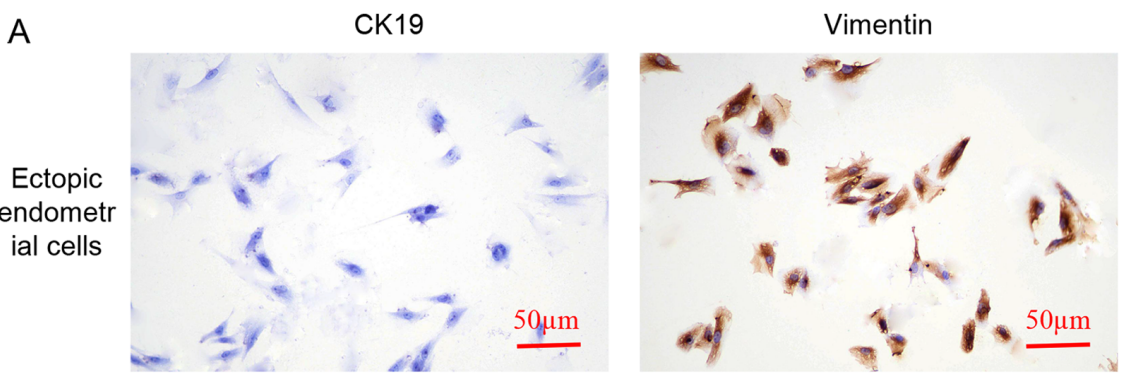

B
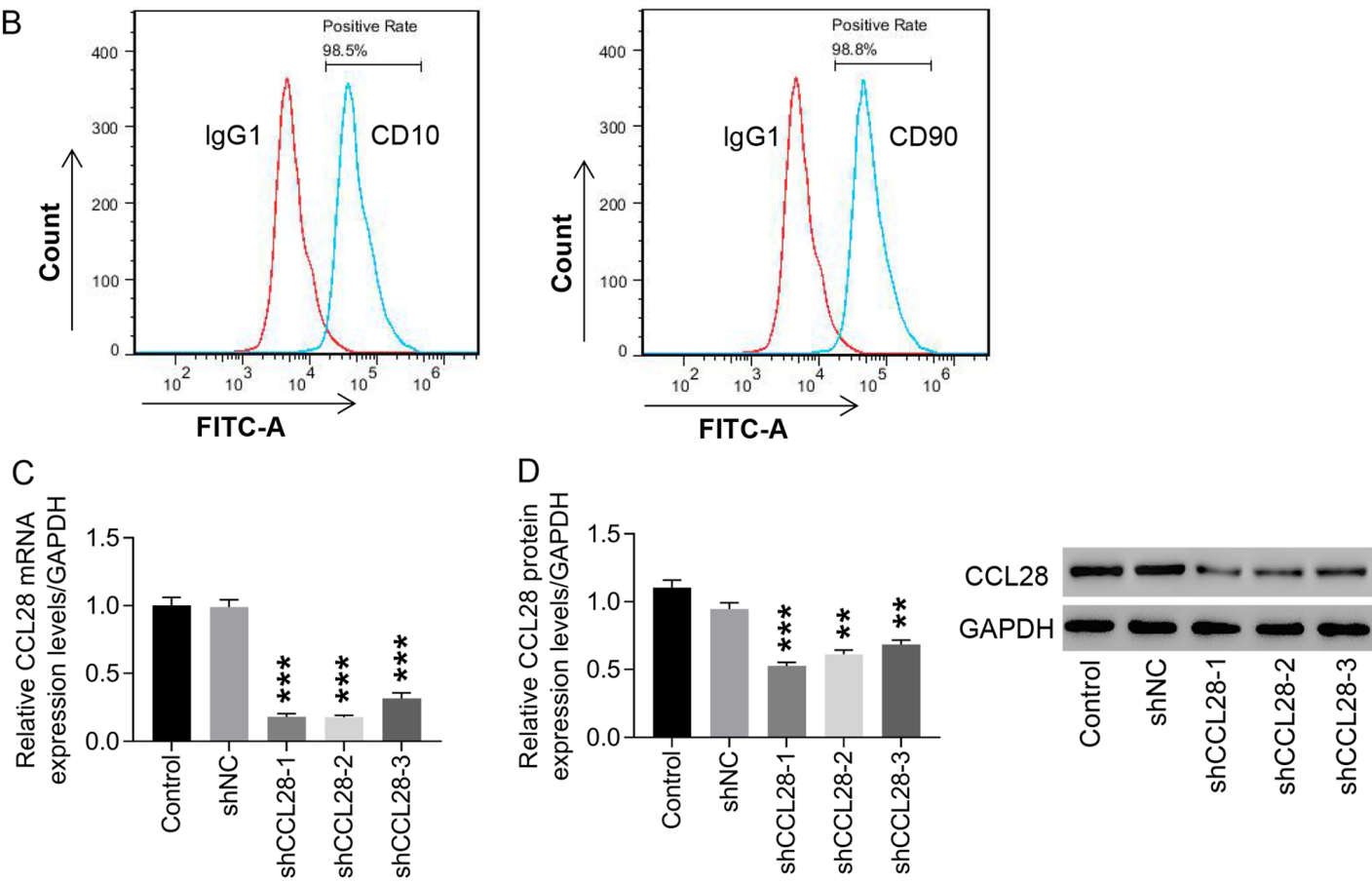

Figure 2. Knockdown of CCL28 expression in endometrial stromal cells by lentiviral transduction. (A) endometrial stromal cells were identified via immunocytochemistry, which was used to analyze CK19 and vimentin expression (x200, $50 \mu \mathrm{m}$ ). (B) CD10 and CD90 were detected using flow cytometry to identify the percentage of EM stromal cells. shCCL28-1, -2 and -3 were constructed to transduce endometrial stromal cells, CCL28 (C) mRNA and (D) protein expression levels were detected to determine the knockdown efficiency of the constructs. ${ }^{* * *} \mathrm{P}<0.01$ and ${ }^{* * * *} \mathrm{P}<0.001$ vs. shNC. Control, cells cultured with medium; shNC, cells infected with negative control lentivirus; shCCL28-1, -2 and -3 , cells transduced with shCCL28 lentivirus-1, -2 and -3; CCL28, C-C motif chemokine ligand 28; sh, short hairpin RNA; CK19, cytokeratin-19.

no significant change was observed (Fig. 4C). In most cases there is still a small increase at $40 \mathrm{ng} / \mathrm{ml}$ and in general the increase in cell proliferation at different concentrations is small. Furthermore, after CCL28 recombinant protein treatment, both mRNA and protein expression levels of CCL28 and CCR10 were significantly increased in a dose-dependent manner compared with $0 \mathrm{ng} / \mathrm{ml}$ (Fig. 4D-F). Although there is still a small increase at $40 \mathrm{ng} / \mathrm{ml}$ and in general the increase of $40 \mathrm{ng} / \mathrm{ml}$ in cell proliferation and expression of CCL28 and CCR10 is smaller than that of $20 \mathrm{ng} / \mathrm{ml}$. Based on these results, $20 \mathrm{ng} / \mathrm{ml} \mathrm{CCL28}$ recombinant protein was selected for the subsequent experiments.

CCL28 may contribute to EM progression by regulating MMP2, MMP9 and ITGB1 expression via activation of the ERK signaling pathway. The mechanism of the ERK signaling pathway in EM progression was explored. The results demonstrated that CCL28-induced proliferation and invasion of healthy endometrial stromal cells were markedly attenuated by PD98059 (ERK inhibitor; Fig. 5A and B). Furthermore, compared with vehicle + DMSO, CCL28 induced the activities of MMP2 and MMP9, which were markedly inhibited by PD98059 (Fig. 5C). CCL28-induced MMP2, MMP9 and ITGB1 protein expression levels, as well as p-ERK/ERK ratio, were significantly decreased by PD98059 (Fig. 5D and E). These results indicated that CCL28 may contribute to EM progression by regulating MMP2, MMP9 and ITGB1 expression via the ERK signaling pathway.

\section{Discussion}

Previous research has suggested that chemokine ligands serve important roles in the development and progression of EM. For example, the levels of CCL2 are elevated in the peritoneal fluid of female patients with EM $(31,32)$, and can enhance endometrial stromal cell survival and invasion (23). A previous study also demonstrated that proinflammatory cytokines contribute to the development of EM by upregulating the secretion of CCL20 in endometrial stromal cells (33). Furthermore, it has been reported that certain chemokines, such as CCL2 and CCL5, have the potential to be biomarkers for EM $(34,35)$. As for chemokine CCL28, a study has revealed that it is elevated 


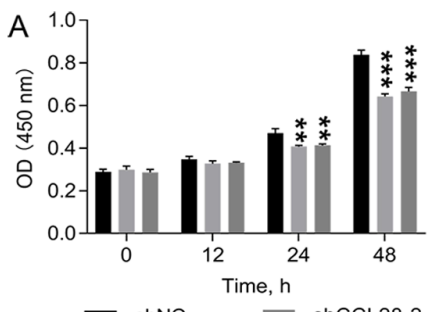

B
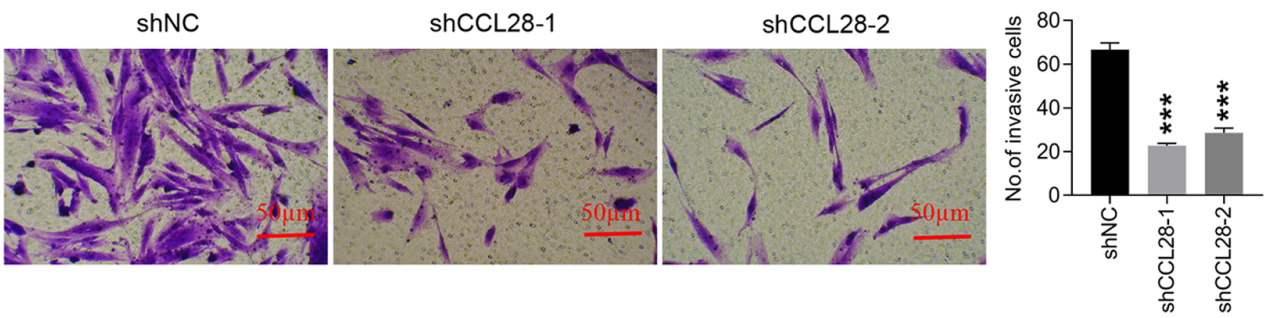

shNC
shCCL28-1
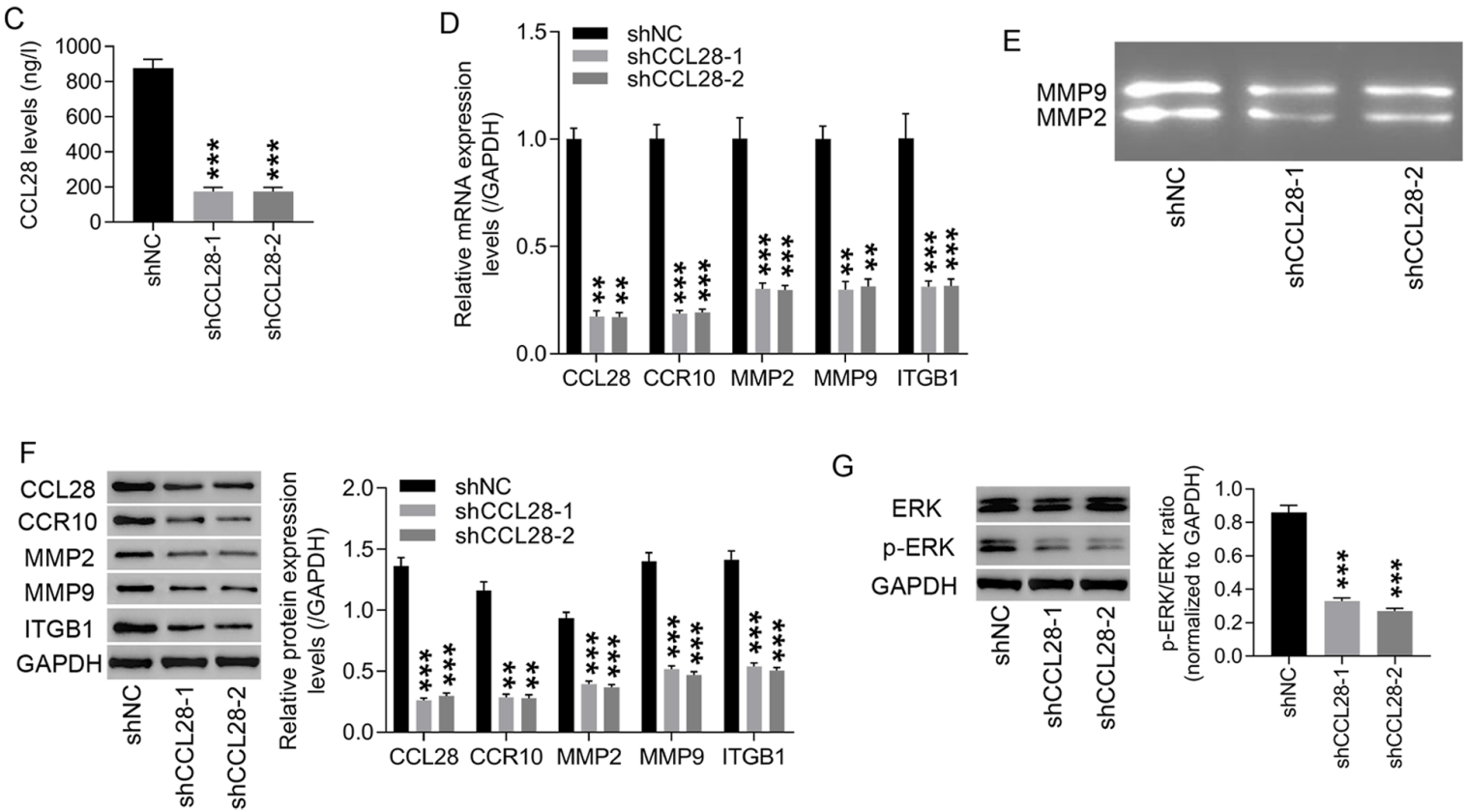

Figure 3. Knockdown of CCL28 in endometrial stromal cells significantly suppresses cell proliferation and invasion. (A) Following CCL28 knockdown in endometrial stromal cells, cell proliferation was detected using a Cell Counting Kit- 8 assay at 0,12,24 and $48 \mathrm{~h}$. (B) Cell invasion at $48 \mathrm{~h}$ was detected using a Transwell invasion assay $(\mathrm{x} 200,50 \mu \mathrm{m})$. (C) CCL28 levels in endometrial stromal cell supernatants were detected using an ELISA. (D) mRNA expression levels of CCL28, CCR10, MMP2, MMP9 and ITGB1 were examined using reverse transcription-quantitative PCR. (E) Activities of MMP2 and MMP9 were detected using gelatinase zymography. (F) Protein expression levels of CCL28, CCR10, MMP2, MMP9 and ITGB1 were detected via western blotting. (G) Protein expression levels of p-ERK/ERK ratio were detected via western blotting. ${ }^{* *} \mathrm{P}<0.01$ and ${ }^{* * *} \mathrm{P}<0.001$ vs. shNC. shNC, cells infected with negative control lentivirus; shCCL28-1 and -2, cells transduced with shCCL28 lentivirus-1 and -2; CCL28, C-C motif chemokine ligand 28; CCR10, CC chemokine receptor 10; ITGB1, integrin $\beta 1$; sh, short hairpin RNA; p, phosphorylated; OD, optical density.

in the serum of patients with celiac disease and decreases following treatment (36). In Helicobacter pylori infection, upregulated CCL28 expression is associated with a risk of gastritis and peptic ulcer disease (37). In the present study, significantly elevated CCL28 expression was observed in the serum and endometrial tissues of patients with EM, alongside significantly increased CCR10 expression. Knockdown of CCL28 in endometrial stromal cells significantly suppressed cell proliferation and invasion. These results are consistent with a report that depletion of CCL27 can suppress cell proliferation and metastasis in ectopic endometrial stromal cells (17). Therefore, these results suggested that CCL28 may serve a critical role in the progression of EM, and knockdown of CCL28 may attenuate EM by inhibiting cell proliferation and invasion.

Furthermore, the potential mechanisms by which CCL28 regulated EM stromal cell proliferation and invasion were investigated. A significant decrease in mRNA and protein expression levels of CCR10, MMP2, MMP9 and ITGB1, as well as decreased ERK1/2 phosphorylation, were observed in shCCL28 endometrial stromal cells. Subsequently, various concentrations of CCL28 recombinant proteins (between 5 and $40 \mathrm{ng} / \mathrm{ml}$ ) were tested on healthy endometrial stromal cells. Although there is still a small increase at $40 \mathrm{ng} / \mathrm{ml}$ and in general the increase of $40 \mathrm{ng} / \mathrm{ml}$ in cell proliferation and expression of CCL28 and CCR 10 is smaller than that of $20 \mathrm{ng} / \mathrm{ml}$. Thus, the concentration of $20 \mathrm{ng} / \mathrm{ml}$ was chosen for subsequent experiments. Treatment with $20 \mathrm{ng} / \mathrm{ml}$ CCL28 recombinant proteins significantly induced cell proliferation and invasion at $48 \mathrm{~h}$, and relative protein levels of MMP2, MMP9, ITGB1 and p-ERK were significantly attenuated by the ERK inhibitor, PD98059. MMPs are important in tumor metastasis as a result of their degradation capacity of extracellular matrix (38). Gelatinases MMP2 and MMP9 are used as prognostic factors in numerous types of solid tumors $(39,40)$. A previous study reported that compared with that in the normal endometrium, expression of MMPs is much greater in ectopic endometrium (41). MMP9 has been reported to be associated with the grade and stage of endometrial cancer, whereas MMP2 expression is related to CA125 expression and clinical progression in endometrial carcinoma $(42,43)$. MMP9 overexpression enhances the invasion of the endometrium 

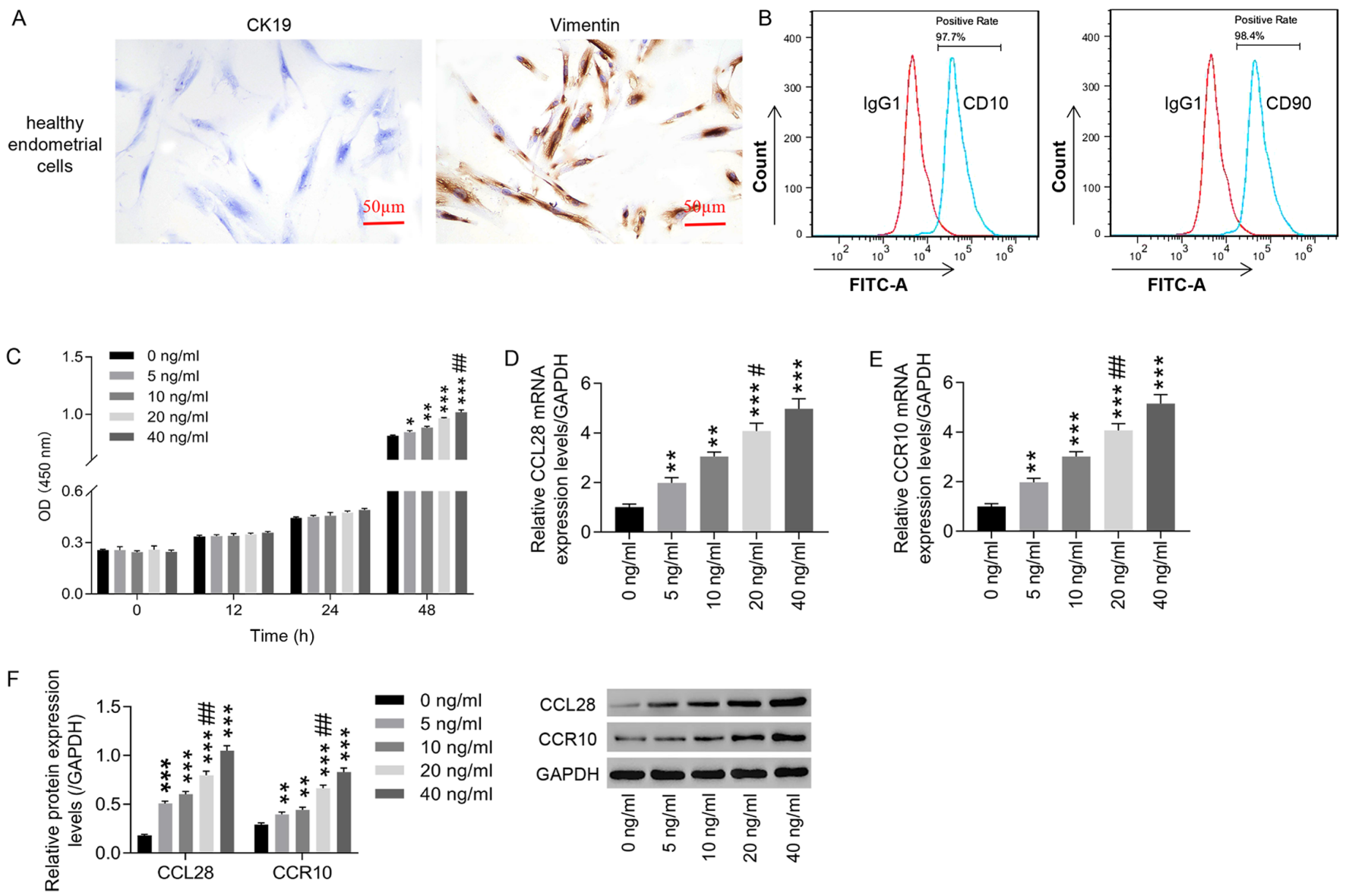

Figure 4. Treatment with CCL28 recombinant protein increases CCL28 and CCR10 expression in healthy human endometrial stromal cells. (A) Healthy human endometrial stromal cells were identified using immunocytochemistry to analyze CK19 and vimentin expression (x200, $50 \mu \mathrm{m}$ ). (B) CD10 and CD90 were detected via flow cytometry to identify the percentage of healthy endometrial stromal cells. Healthy human endometrial stromal cells were then treated with CCL28 recombinant protein at concentrations of $0,5,10,20$ and $40 \mathrm{ng} / \mathrm{ml}$. (C) Cell proliferation was detected using a Cell Counting Kit- 8 assay to determine the effect of CCL28 recombinant protein. Subsequently, at $48 \mathrm{~h}$ after CCL28 recombinant protein treatment, the mRNA expression levels of (D) CCL28 and (E) CCR10 were detected using reverse transcription-quantitative PCR. (F) Relative protein expression levels of CCL28 and CCR10 were analyzed via western blotting at $48 \mathrm{~h}$ after CCL28 recombinant protein treatment. ${ }^{*} \mathrm{P}<0.05,{ }^{* *} \mathrm{P}<0.01$ and ${ }^{* * * *} \mathrm{P}<0.001 \mathrm{vs} .0 \mathrm{ng} / \mathrm{ml}$; and ${ }^{\#} \mathrm{P}<0.05$ and ${ }^{\# \#} \mathrm{P}<0.01 \mathrm{vs}$. $10 \mathrm{ng} / \mathrm{ml}$. CCL28, C-C motif chemokine ligand 28; CCR10, CC chemokine receptor 10; CK19, cytokeratin-19; OD, optical density.

and the ability to degrade the extracellular matrix, loosening the connection between cells, thereby providing allowing ectopic endometrial tissue to enter the myometrium (44). MMP9 may also be involved in the formation of lesion blood vessels, providing nutrition for ectopic endometrium (45-47). Furthermore, previous studies have reported that the ERK1/2 signaling pathway is linked to EM progression, such as in endometriotic cell migration and apoptosis $(20,22)$. It has also been demonstrated that estrogen can upregulate the expression levels of MMP2/MMP9 in endometrial epithelial cells via the VEGF-ERK1/2 signaling pathway (48). Furthermore, long non-coding RNA BRAF-activated non-protein coding RNA, can promote cell proliferation and invasion in endometrial cancer cells by regulating MMP2 and MMP1 via the ERK/MAPK signaling pathway (49). The present study demonstrated that CCL28 knockdown markedly inhibited the activities of MMP2 and MMP9, whereas CCL28 induced MMP2 and MMP9 activity, which was counteracted by the ERK inhibitor PD98059. Therefore, it can be inferred that CCL28 may promote endometrial stromal cell proliferation and invasion by regulating MMP2 and MMP9 via the ERK signaling pathway.
Integrins are important adhesion molecules on the surface of endometrial cells, are closely related to the pathogenesis of EM and serve important roles in signal transduction (50). ITGB1 is a member of the integrins. ITGB1 expression has been demonstrated to be upregulated in the endometrium of patients with EM, with microRNA-183 impacting EM progression by regulating stromal cell ITGB1 expression and function (51).

In the present study, ITGB1 expression was positively regulated by CCL28, and this was counteracted by the ERK inhibitor PD98059. Therefore, these results indicated that CCL28 may also regulate ITGB1 expression and function in endometrial stromal cells via the ERK signaling pathway. However, the effect of CCL28 on the development of EM was only investigated at the cellular level. Therefore, in vivo experiments are required to further confirm the therapeutic effect of CCL28 on EM and further explore underlying molecular mechanisms to expand the clinical application of CCL28. Although additional studies are required to further verify the function and mechanisms of CCL28 in the development of EM, the present study implied that CCL28 could be considered as a potential target for EM treatment. 


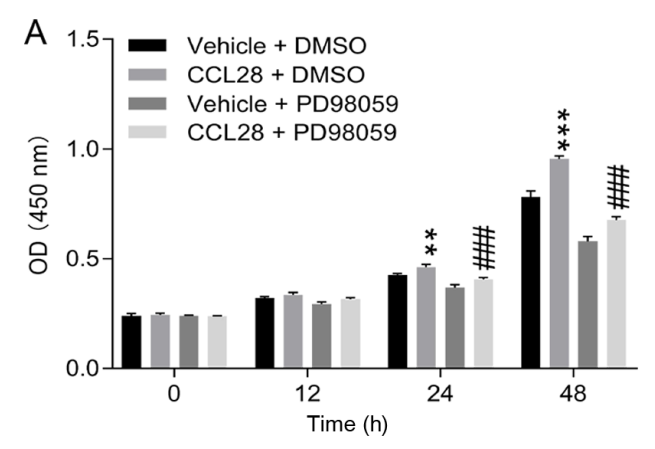

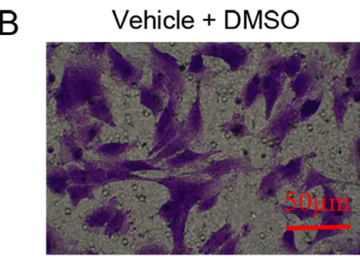

Vehicle + PD98059

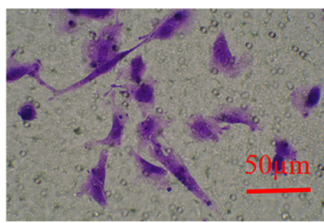

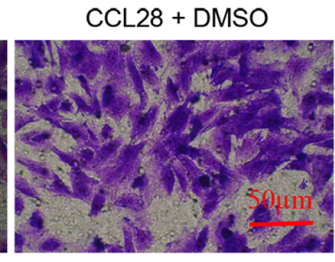

CCL28 + PD98059

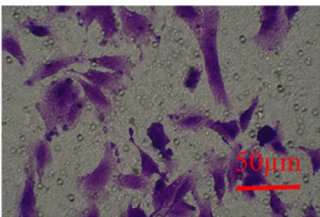

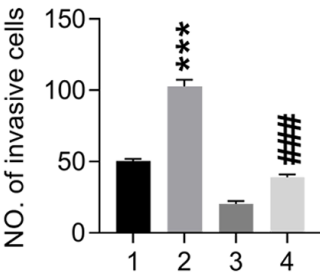

1: Vehicle + DMSO

2: CCL28 + DMSO

3: Vehicle + PD98059

4: CCL28 + PD98059
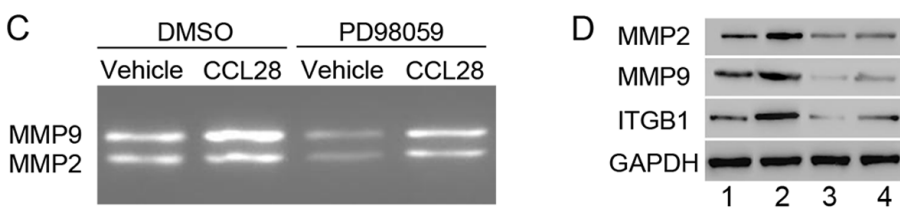

1: Vehicle + DMSO

2: CCL28 + DMSO

3: Vehicle + PD98059

4: CCL28 + PD98059
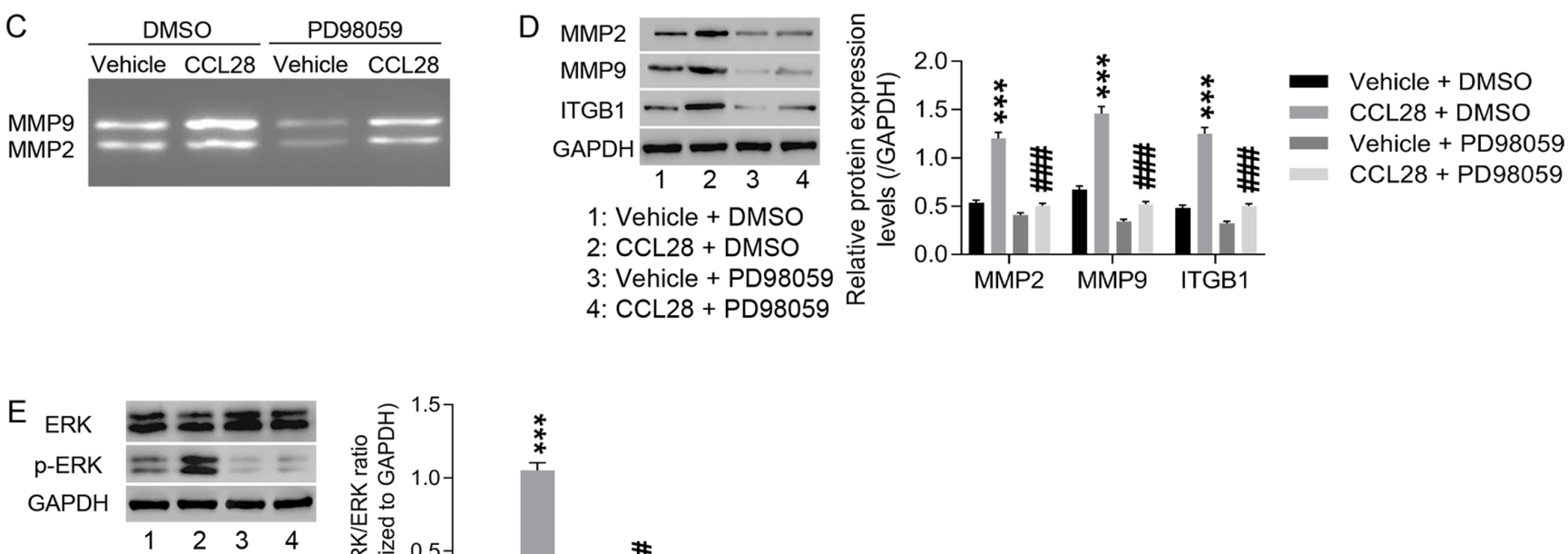

1: Vehicle + DMSO

2: $\mathrm{CCL} 28+\mathrm{DMSO}$

3: Vehicle + PD98059

4: CCL28 + PD98059

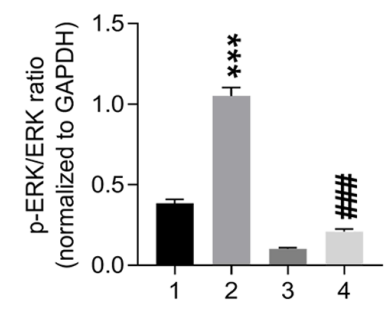

Figure 5. CCL28 may contribute to endometriosis progression by regulating MMP2, MMP9 and ITGB1 expression via activating the ERK signaling pathway Healthy endometrial stromal cells were pre-treated with $10 \mu \mathrm{mol} / 1$ PD98059 (ERK inhibitor) for $30 \mathrm{~min}$, and then treated with $20 \mathrm{ng} / \mathrm{ml} \mathrm{CCL28} \mathrm{recom-}$ binant protein for $48 \mathrm{~h}$. (A) Cell proliferation was detected using the Cell Counting Kit-8 assay at 0, 12, 24 and $48 \mathrm{~h}$. (B) Cell invasion was detected using the Transwell invasion assay at $48 \mathrm{~h}(\mathrm{x} 200,50 \mu \mathrm{m})$. (C) MMP2 and MMP9 activity was detected via gelatinase zymography. Relative protein expression levels of (D) MMP2, MMP9 and ITGB1 and (E) the p-ERK/ERK ratio were analyzed via western blotting. ${ }^{* *} \mathrm{P}<0.01,{ }^{* * *} \mathrm{P}<0.001$ vs. vehicle + DMSO; and ${ }^{\# \# \# P} \mathrm{P}<0.001$ vs. CCL28 + vehicle. Vehicle, solvent of CCL28 recombinant proteins; DMSO, solvent of PD98059; CCL28, C-C motif chemokine ligand 28; ITGB1, integrin $\beta 1 ; p$, phosphorylated; OD, optical density.

\section{Acknowledgements}

Not applicable.

\section{Funding}

The present study was supported by the Shanghai Youth Clinical Medical Personnel (Clinical Laboratory Specialty) Training Scheme (grant no. 201605).

\section{Availability of data and materials}

All data generated or analyzed during this study are included in this published article.

\section{Authors' contributions}

HC and QZ conceived and designed the study. YW, FZ, WSu and WSh performed the experiments and collected and analyzed the data. HC and QZ wrote and revised the manuscript. HC and QZ have confirmed the authenticity of all the raw data. All authors have read and approved the final manuscript.

\section{Ethics approval and consent to participate}

All experiments conducted in the present study were approved by the Ethics Committee of Shanghai First Maternity and Infant Hospital, School of Medicine, Tongji University (approval no. KS2154; Shanghai, China), and written informed consent was obtained.

\section{Patient consent for publication}

Not applicable.

\section{Competing interests}

The authors declare that they have no competing interests. 


\section{References}

1. Kennedy S, Bergqvist A, Chapron C, D'Hooghe T, Dunselman G Greb R, Hummelshoj L, Prentice A and Saridogan E; ESHRE Special Interest Group for Endometriosis and Endometrium Guideline Development Group: ESHRE guideline for the diagnosis and treatment of endometriosis. Hum Reprod 20: 2698-2704, 2005

2. Eskenazi B and Warner ML: Epidemiology of endometriosis. Obstet Gynecol Clin North Am 24: 235-258, 1997.

3. Zondervan KT, Yudkin PL, Vessey MP, Jenkinson CP, Dawes MG Barlow DH and Kennedy SH: The community prevalence of chronic pelvic pain in women and associated illness behaviour. Br J Gen Pract 51: 541-547, 2001.

4. Zondervan KT, Cardon LR and Kennedy SH: What makes a good case-control study? Design issues for complex traits such as endometriosis. Hum Reprod 17: 1415-1423, 2002.

5. Rogers PA, D'Hooghe TM, Fazleabas A, Gargett CE, Giudice LC, Montgomery GW, Rombauts L, Salamonsen LA and Zondervan KT: Priorities for endometriosis research: Recommendations from an international consensus workshop. Reprod Sci 16: 335-346, 2009.

6. Rolla E: Endometriosis: Advances and controversies in classification, pathogenesis, diagnosis, and treatment. F1000 Res 8: 8, 2019.

7. Liu J, Wang Y, Chen P, Ma Y, Wang S, Tian Y, Wang A and Wang D: AC002454.1 and CDK6 synergistically promote endometrial cell migration and invasion in endometriosis. Reproduction 157: 535-543, 2019.

8. Bakogiannis C, Sachse M, Stamatelopoulos K and Stellos K: Platelet-derived chemokines in inflammation and atherosclerosis Cytokine 122: 154157, 2019.

9. Korbecki J, Grochans S, Gutowska I, Barczak K and Baranowska-Bosiacka I: CC Chemokines in a tumor: A review of pro-cancer and anti-cancer properties of receptors CCR5, CCR6, CCR7, CCR8, CCR9, and CCR10 ligands. Int J Mol Sci 21: 21, 2020

10. Bian X, Xiao YT, Wu T, Yao M, Du L, Ren S and Wang J: Microvesicles and chemokines in tumor microenvironment: Mediators of intercellular communications in tumor progression. Mol Cancer 18: 50, 2019.

11. Hieshima K, Ohtani H, Shibano M, Izawa D, Nakayama T, Kawasaki Y, Shiba F, Shiota M, Katou F, Saito T, et al: CCL28 has dual roles in mucosal immunity as a chemokine with broad-spectrum antimicrobial activity. J Immunol 170: 1452-1461, 2003.

12. Berri M, Virlogeux-Payant I, Chevaleyre C, Melo S, Zanello G Salmon H and Meurens F: CCL28 involvement in mucosal tissues protection as a chemokine and as an antibacterial peptide. Dev Comp Immunol 44: 286-290, 2014

13. Moed H, Boorsma DM, Tensen CP, Flier J, Jonker MJ, Stoof TJ, von Blomberg BM, Bruynzeel DP, Scheper RJ, Rustemeyer T, et al: Increased CCL27-CCR10 expression in allergic contact dermatitis: implications for local skin memory. Journal Pathol 204: 39-46, 2004.

14. Chen L, Liu X, Zhang H-Y, Du W, Qin Z, Yao Y, Mao Y and Zhou L: Upregulation of chemokine receptor CCR10 is essential for glioma proliferation, invasion and patient survival. Oncotarget 5: 6576-6583, 2014

15. Xiong N, Fu Y, Hu S, Xia M and Yang J: CCR10 and its ligands in regulation of epithelial immunity and diseases. Protein Cell 3 . 571-580,2012.

16. Lin HY, Sun SM, Lu XF, Chen PY, Chen CF, Liang WQ and Peng CY: CCR10 activation stimulates the invasion and migration of breast cancer cells through the ERK1/2/MMP-7 signaling pathway. Int Immunopharmacol 51: 124-130, 2017.

17. Ruan F, Ma J and Zhou J: Depletion of CCL27 inhibits cell proliferation, metastasis and adhesion in ectopic endometrial stromal cells. Int J Clin Exp Med 9: 19074-19083, 2016.

18. Sun C, Zhang YY, Tang CL, Wang SC, Piao HL, Tao Y, Zhu R, Du MR and Li DJ: Chemokine CCL28 induces apoptosis of decidual stromal cells via binding CCR3/CCR10 in human spontaneous abortion. Mol Hum Reprod 19: 676-686, 2013.

19. Cha HR, Ko HJ, Kim ED, Chang SY, Seo SU, Cuburu N, Ryu S, Kim S and Kweon MN: Mucosa-associated epithelial chemokine/CCL28 expression in the uterus attracts CCR10 ${ }^{+} \operatorname{IgA}$ plasma cells following mucosal vaccination via estrogen control. J Immunol 187: 3044-3052, 2011.

20. Gentilini D, Busacca M, Di Francesco S, Vignali M, Viganò P and Di Blasio AM: PI3K/Akt and ERK1/2 signalling pathways are involved in endometrial cell migration induced by $17 \beta$-estradiol and growth factors. Mol Hum Reprod 13: 317-322, 2007.
21. Tong JS, Zhang QH, Huang X, Fu XQ, Qi ST, Wang YP, Hou Y, Sheng J and Sun QY: Icaritin causes sustained ERK1/2 activation and induces apoptosis in human endometrial cancer cells. PLoS One 6: e16781, 2011

22. Banu SK, Lee J, Speights VO Jr, Starzinski-Powitz A and Arosh JA: Selective inhibition of prostaglandin E2 receptors EP2 and EP4 induces apoptosis of human endometriotic cells through suppression of ERK1/2, AKT, NFkappaB, and $\beta$-catenin pathways and activation of intrinsic apoptotic mechanisms. Mol Endocrinol 23: 1291-1305, 2009.

23. Li MQ, Li HP, Meng YH, Wang, Zhu XY, Mei J and Li DJ: Chemokine CCL2 enhances survival and invasiveness of endometrial stromal cells in an autocrine manner by activating Akt and MAPK/Erk1/2 signal pathway. Fertil Steril 97: 919-929, 2012.

24. Li MQ, Shao J, Meng YH, Mei J, Wang Y, Li H, Zhang L, Chang KK, Wang XQ, Zhu XY, et al: NME1 suppression promotes growth, adhesion and implantation of endometrial stromal cells via Akt and MAPK/Erk1/2 signal pathways in the endometriotic milieu. Hum Reprod 28: 2822-2831, 2013.

25. Yang XL, Liu KY, Lin FJ, Shi HM and Ou ZL: CCL28 promotes breast cancer growth and metastasis through MAPK-mediated cellular anti-apoptosis and pro-metastasis. Oncol Rep 38: 1393-1401, 2017

26. Liu J, Zhang Z, Liu J and Wang D: LIM Kinase 1 Mediates estradiol effects on the phosphorylation of Cofilin1 in eutopic endometrial stromal cells during the invasion and proliferation of endometriosis. Reprod Sci 26: 1499-1505, 2019.

27. Chen Q, Hang Y, Zhang T, Tan L, Li S and Jin Y: USP10 promotes proliferation and migration and inhibits apoptosis of endometrial stromal cells in endometriosis through activating the Raf-1/MEK/ERK pathway. Am J Physiol Cell Physiol 315: C863-C872, 2018

28. Livak KJ and Schmittgen TD: Analysis of relative gene expression data using real-time quantitative PCR and the $2^{-\Delta \Delta C T}$ method. Methods 25: 402-408, 2001

29. Minkwitz C, Schoon HA, Zhang Q and Schöniger S: Plasticity of endometrial epithelial and stromal cells-A new approach towards the pathogenesis of equine endometrosis. Reprod Domest Anim 54: 835-845, 2019.

30. Deng X, Zhang X, Li W, Feng RX, Li L, Yi GR, Zhang XN, Yin C, Yu HY, Zhang JP, et al: Chronic Liver Injury Induces Conversion of Biliary Epithelial Cells into Hepatocytes. Cell Stem Cell 23: 114-122 e3, 2018

31. Gou Y, Li X, Li P, Zhang H, Xu T, Wang H, Wang B, Ma X, Jiang $X$ and Zhang Z: Estrogen receptor $\beta$ upregulates CCL2 via NF- $\kappa \mathrm{B}$ signaling in endometriotic stromal cells and recruits macrophages to promote the pathogenesis of endometriosis. Hum Reprod 34: 646-658, 2019.

32. Mei J, Zhou WJ, Li SY, Li MQ and Sun HX: Interleukin-22 secreted by ectopic endometrial stromal cells and natural killer cells promotes the recruitment of macrophages through promoting CCL2 secretion. Am J Reprod Immunol 82: e13166, 2019.

33. Hirata T, Osuga Y, Takamura M, Kodama A, Hirota Y, Koga K, Yoshino O, Harada M, Takemura Y, Yano T, et al: Recruitment of CCR6-expressing Th17 cells by CCL20 secreted from IL-1 $\beta-$ TNF- $\alpha-$, and IL-17A-stimulated endometriotic stromal cells. Endocrinology 151: 5468-5476, 2010.

34. Guo P, Bi K, Lu Z, Wang K, Xu Y, Wu H, Cao Y and Jiang H: CCR5/CCR5 ligand-induced myeloid-derived suppressor cells are related to the progression of endometriosis. Reprod Biomed Online 39: 704-711, 2019.

35. Jaiswal U, Yadav RK, Bhat MA, Kriplani A, Roy KK and Netam RK: Cytokine and growth factor profile in endometriosis: a multiplex analysis of peritoneal fluid to assess diagnostic utility. Gynecol Endocrinol 36: 718-722, 2020.

36. Rashidiani S, Jalili A, Babaei E, Sheikhesmaeili F, Fakhari S, Ataee P and Parhizkar B: The chemokine CCL28 is elevated in the serum of patients with celiac disease and decreased after treatment. Am J Clin Exp Immunol 6: 60-65, 2017.

37. Sanaei MJ, Shirzad H, Soltani A, Abdollahpour-Alitappeh M, Shafigh MH, Rahimian G, Mirzaei Y and Bagheri N: Up-regulated CCL18, CCL28 and CXCL13 expression is associated with the risk of gastritis and peptic ulcer disease in Helicobacter pylori infection. Am J Med Sci361: 43-54, 2021.

38. Lv Y, Zhao X, Zhu L, Li S, Xiao Q, He W and Yin L: Targeting intracellular MMPs efficiently inhibits tumor metastasis and angiogenesis. Theranostics 8: 2830-2845, 2018.

39. Wang X, Yang B, She Y and Ye Y: The IncRNA TP73-AS1 promotes ovarian cancer cell proliferation and metastasis via modulation of MMP2 and MMP9. J Cell Biochem 119: 7790-7799, 2018. 
40. Farina P, Tabouret E, Lehmann P, Barrie M, Petrirena G, Campello C, Boucard C, Graillon T, Girard N and Chinot O Relationship between magnetic resonance imaging characteristics and plasmatic levels of MMP2 and MMP9 in patients with recurrent high-grade gliomas treated by Bevacizumab and Irinotecan. J Neurooncol 132: 433-437, 2017.

41. Pino M, Galleguillos C, Torres M, Sovino H, Fuentes A Boric MA and Johnson MC: Association between MMP1 and MMP9 activities and ICAM1 cleavage induced by TNF in stromal cell cultures from eutopic endometria of women with endometriosis. Reproduction 138: 837-847, 2009.

42. Aglund K, Rauvala M, Puistola U, Angström T, TurpeenniemiHujanen T, Zackrisson B and Stendahl U: Gelatinases A and B (MMP-2 and MMP-9) in endometrial cancer-MMP-9 correlates to the grade and the stage. Gynecol Oncol 94: 699-704, 2004

43. Honkavuori M, Talvensaari-Mattila A, Soini Y, TurpeenniemiHujanen T and Santala M: MMP-2 expression associates with CA 125 and clinical course in endometrial carcinoma. Gynecol Oncol 104: 217-221, 2007.

44. Barbe AM, Berbets AM, Davydenko IS, Koval HD, Yuzko VO and Yuzko OM: Expression and significance of matrix metalloproteinase-2 and matrix metalloproteinas-9 in Endometriosis. J Med Life 13: 314-320, 2020.

45. Freitas S, Meduri G, Le Nestour E, Bausero P and PerrotApplanat M: Expression of metalloproteinases and their inhibitors in blood vessels in human endometrium. Biol Reprod 61: 1070-1082, 1999.

46. Yoshiji H, Harris SR, Raso E, Gomez DE, Lindsay CK, Shibuya M, Sinha CC and Thorgeirsson UP: Mammary carcinoma cells over-expressing tissue inhibitor of metalloproteinases-1 show enhanced vascular endothelial growth factor expression. Int J Cancer 75: 81-87, 1998.
47. Kodarahmian M, Amidi F, Moini A, Kashani L, Nashtaei MS, Pazhohan A, Bahramrezai M, Berenjian S and Sobhani A: The modulating effects of resveratrol on the expression of MMP-2 and MMP-9 in endometriosis women: A randomized exploratory trial. Gynecol Endocrinol 35: 719-726, 2019.

48. Shan B,Li W, Yang SY and Li ZR: Estrogen up-regulates MMP2/9 expression in endometrial epithelial cell via VEGF-ERK1/2 pathway. Asian Pac J Trop Med 6: 826-830, 2013.

49. Wang D, Wang D, Wang N, Long Z and Ren X: Long non-coding RNA BANCR promotes endometrial cancer cell proliferation and invasion by regulating MMP2 and MMP1 via ERK/MAPK signaling pathway. Cell Physiol Biochem 40: 644-656, 2016.

50. Lei Y, Huang K, Gao C, Lau QC, Pan H, Xie K, Li J, Liu R, Zhang T, Xie N, et al: Proteomics identification of ITGB3 as a key regulator in reactive oxygen species-induced migration and invasion of colorectal cancer cells. Mol Cell Proteomics: May 27, 2011 (Epub ahead of print). doi: 10.1074/mcp.M110.005397.

51. Chen J, Gu L, Ni J, Hu P, Hu K and Shi YL: MiR-183 regulates ITGB1P expression and promotes invasion of endometrial stromal cells. Biomed Res Int 2015: 340218, 2015.

This work is licensed under a Creative Commons Attribution-NonCommercial-NoDerivatives 4.0 International (CC BY-NC-ND 4.0) License. 